\title{
Low-grade fibromyxoid sarcoma of the vagina: A tumor, not previously reported at this site
}

\section{Vajenin düşük-dereceli fibromiksoid sarkomu: Bu konumda daha önce bildirilmemiş bir tümör}

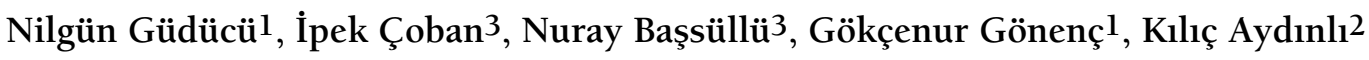 \\ ${ }^{1}$ İstanbul Bilim University Faculty of Medicine, Department of Obstetrics and Gynecology, Ístanbul, Turkey \\ 2İstanbul University Cerrahpaşa Faculty of Medicine, Department of Obstetrics and Gynecology, İstanbul, Turkey \\ 3ístanbul Bilim University Faculty of Medicine, Department of Pathology, İstanbul, Turkey
}

\begin{abstract}
This report presents the first case of low-grade fibromyxoid sarcoma (LGFMS) arising from the vaginal wall (a rare soft-tissue sarcoma of subfascial planes) and draws attention to differential diagnosis of masses arising from the vaginal wall. A patient presenting with abdominal pain to emergency department was diagnosed to have an ovarian mass filling the Douglas space. At laparoscopy, the origin of the mass was identified as the posterior vaginal wall. After vaginal excision of the gelatinous mass, pathologic diagnosis revealed a rare tumor, LGFMS. We discussed the differential diagnosis of vaginal LGFMS. J Turk Soc Obstet Gynecol 2014;3:196-7
\end{abstract}

Key Words: Low-grade fibromyxoid sarcoma, vagina, mesenchymal

\section{Özet}

Bu rapor vajen duvarından kaynaklanan ilk düşük-gradeli fibromiksoid sarkom (DGFMS) olgusunu sunmakta ve vajen duvarından kaynaklanan kitlelerin ayırıcı tanısına dikkat çekmektedir. Karın ağrısı nedeniyle acil bölümüne başvuran hastaya Douglas boşluğunu dolduran ovaryan kitle tanısı konmuştur. Hastanemizde yapılan laparoskopide kitlenin kaynağının vajen arka duvarı olduğu görüldü. Jelatinöz yapıdaki kitlenin vajinal eksizyonundan sonra patolojik tanı nadir bir tümör olan DGFMS olarak geldi. Biz de vajinal DGFMS'nin ayırıcı tanısını tartıştık. J Turk Soc Obstet Gynecol 2014;3:196-7

Anahtar Kelimeler: Düşük-dereceli fibromiksoid sarkom, mazensimal, vajen

\section{Introduction}

Low-grade fibromyxoid sarcoma (LGFMS) is a rare soft-tissue sarcoma that presents in subfascial planes as an isolated tumoral mass and it was first described by Evans in 1987(1). The specious benign appearance may end up with local recurrence or metastasis at an unpredictable time in the future. LGFMSs are mostly described as tumors of trunk and lower extremities. To the best of our knowledge there is no LGFMS of the vagina reported before, literature review revealed two vulvar and one ovarian $\operatorname{LGFMS}(2,3)$. This report aimed to present the first LGFMS arising from the vaginal wall and to draw attention to differential diagnosis of future masses arising from the vaginal wall.

\section{Case}

A 36 years old woman presented with abdominal pain to emergency department of a private hospital. Her magnetic resonance imaging report revealed a $6 \mathrm{~cm}$ ovarian cyst (Figure 1A). She was referred to an outpatient gynecology clinic after exclusion of acute abdomen. She went to her own gynecologist, where she had her last gynecologic examination and transvaginal ultrasound 14 months ago with completely normal findings. At the outpatient clinic a mass filling Douglas space and protruding into the posterior vagina was easily recognized. Transvaginal ultrasonography revealed a septated ovarian mass. She was scheduled to laparoscopic ovarian cystectomy in our hospital. She was prepared in gynecologic position for laparoscopy, after the introduction of the umbilical trocar, inspection revealed normal appearing ovaries and a mass filling Douglas space and most probably arising from the posterior vaginal wall. We decided to end laparoscopy and proceed with vaginal excision of the mass. We made an incision on the mass protruding to posterior vaginal fornix and easily extracted a semisolid, partly encapsulated gelatinous mass. The encapsulated mass measured 9x6x4 cm. Macroscopically the tumor had a yellowwhite gelatinous form and glistening appearance giving the impression of a myxoid substance accumulation (Figure 1B).

Address for Correspondence/Yazışma Adresi: Nilgün Güdücü, MD,

İstanbul Bilim University Faculty of Medicine, Department of Obstetrics and Gynecology, İstanbul, Turkey

Phone:+902122128811 E-mail: nilgun.kutay@gmail.com

Received /Geliş Tarihi : 31.12.2013

Accepted/Kabul Tarihi : 28.01.2014 
Microscopically the tumor had fibrous and myxoid areas, a swirling growth pattern with benign appearing fibroblastic spindle cells dispersed inbetween, there were a few mitotic figures, low-to-moderate cellularity and mild nuclear atypia, there were no necrotic areas and nuclear pleomorphism was slight, the capillary network was rich, the capsule was fragmented and it was impossible to determine positivity of the surgical margins (Figure 1C-F). Immunohistochemical staining with S-100 was performed. The diagnosis was LGFMS of the vaginal wall and the patient was referred to radiotherapy.

\section{Discussion}

Differential diagnosis of vaginal mass lesions includes cysts arising from müllerian remnants. Most of these cystic lesions are benign and they grow anteriorly towards bladder, but aberrant embryological development may leave remnants of Gartner's duct anywhere in the vagina and Gartner's duct cysts in posterior vaginal wall has been reported previously(3). Most of these cystic lesions are asymptomatic and are diagnosed during routine gynecologic examination and do not require any intervention. Malignant transformation of Gartner's duct cysts are rare ${ }^{(4)}$. Other cystic malignant lesions arising from the vaginal wall are also rare and include vaginal squamous cell carcinoma(5). Mesenchymal lesions of the vagina pose a diagnostic challenge to the pathologist and include leiomyoma, leiomyosarcoma, schwannoma, angiomyofibroblastoma, aggressive angiomyxoma, cellular angiofibroma, superficial myofibroblastoma of the lower female genital tract and gastrointestinal stromal tumors $(6,7)$. A mass lesion in Douglas

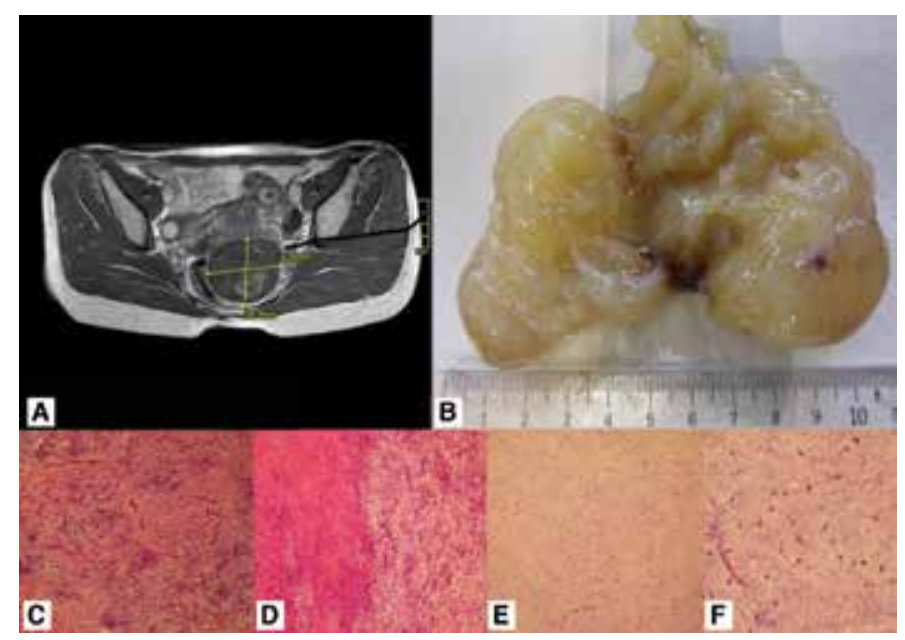

Figure 1A. MRI of the mass filling Douglas space and protruding into posterior vaginal wall

Figure 1B. Macroscopically yellow-white colored, gelatinous mass

Figure 1C. Myxoid areas revealed a rich capillary network

Figure 1D. Alternating areas with fibrous (left) and myxoid (right) stroma are apperant

Figure 1E. Myxoid zone of the lesion is of low cellularity and omposed of bland spindle shaped cells

Figure 1F. At high power, the tumor cells were deeptively bland and some of the cells exhibited a stellate morphology. Mitotic figures were scarce pouch with a similar clinical presentation to our case was reported as adenoma malignum(8). Differential diagnosis of mass lesions presenting in the lower parts of the vagina may also include cysts of Bartholin's gland. In the differential diagnosis of most of the lesions immunohistochemistry was reported to have a limited role and the diagnosis mainly depended on morphology $(9)$.

The gynecological examination of our case was completely normal 14 months ago, but preoperative duration of LGFMS has been reported to range from 1 month to 25 years(10). The case presented here is of additional interest and importance because of its location. Previously LGFMS cases have been reported from vulva and ovary but this will be the first case reported to develop from the vaginal wall.

The largest case series of LGFMS reported by Evans were treated with excision initially, local recurrences and metastases were also mostly treated by excision(10). They sometimes used adjunctive radiotherapy and chemotherapy. Our case has been recently diagnosed and operated, therefore we cannot give data regarding disease free survival, but previously reported deaths due to tumor recurrence occurred at a range of 3 to 42 years, also the author reported survival with tumor upto 70 years(10).

In conclusion, most of the mass lesions of vagina are benign lesions but malignancies including LGFMS must be remembered in the differential diagnosis. These tumors have a highly variable overall prognosis and avoidance of intraabdominal operation may affect survival.

\section{References}

1. Evans HL. Low-grade fibromyxoid sarcoma. A report of two metastasizing neoplasms having a deceptively benign appearance. Am J Clin Pathol 1987;88:615-9.

2. VanSandt AM, Bronson J, Leclair C, Mansoor A, Goetsch M. Lowgrade fibromyxoid sarcoma of the vulva: a case report. J Low Genit Tract Dis 2013;17:79-81.

3. Brown KL, Segal AJ, Hurd GB. An unusual cyst of the vaginal wall: mucous cyst of mid posterior vaginal wall, Gartner ducttype, complicated by rectovaginal septum abscess. Ann Surg 1957;145:423-7.

4. Bats AS, Metzger U, Le frere-Belda MA, Brisa M, Lecuru F. Malignant transformation of Gartner cyst. Int J Gynecol Cancer 2009;19:1655-7.

5. Eltabbakh GH, Field JM, Trask CE, McDay JB, Swift PD. Primary vaginal squamous cell carcinoma presenting as a cystic pelvic mass. Gynecol Oncol 2000;76:213-7.

6. McCluggage WG. Recent developments in vulvovaginal pathology. Histopathology 2009;54:156-73.

7. Lam MM, Corless CL, Goldblum JR, Heinrich MC, Downs-Kelly E, Rubin BP. Extragastrointestinal tumors presenting as vulvovaginal/rectovaginal septal masses: a diagnostic pitfall. Int J Gynecol Pathol 2006;25:288-92.

8. Gotoh T, Kikuchi Y, Takano M, Kita T, Ogata S, Aida S, et al. An extremely rare case of adenoma malignum with large cystic tumor which resulted in urinary obstruction. Gynecol Oncol 2002;84:339-43.

9. McCluggage WG. A review and update of morphologically bland vulvovaginal mesenchymal lesions. Int J Gynecol Pathol 2005;24:26-38

10. Evans HL. Low-grade fibromyxoid sarcoma: a clinicopathologic study of 33 cases with long-term follow-up. Am J Surg Pathol 2011;35:1450-62. 